\title{
THE ROLE OF PARENTAL INVOLVEMENT TOWARDS THE STUDENTS' LEARNING MOTIVATION
}

\author{
Hendita Rifki Alfiansyah \\ Universitas Negeri Yogyakarta \\ Jalan Colombo No.1, Karang Malang, Daerah Istimewa Yogyakarta \\ Email: henditarifky@gmail.com
}

\begin{abstract}
:
This research aimed to identify the role of parental involvement toward the students' learning motivation. This research was conducted using quantitative method. The approach of this research was ex-post facto. The subjects of the research were 136 fourth grade students of elementary school. The instrument of the research used was questionnaire. The technique of data analysis was regression analysis. The result of the research showed that the parental involvement role on learning motivation reaches $39.7 \%$. It could be concluded that the parental involvement role has positive effect on the fourth grade students' learning motivation. This research showed the importance of parental involvement role towards students' learning motivation. These results were expected to provide understanding from the school committee to assure parents that their supports were important in the process of their children education. Therefore, all parties should be involved in improving the quality of children's education.
\end{abstract}

\begin{abstract}
Abstrak:
Penelitian ini bertujuan untuk mengkaji peranan orang tua terhadap motivasi belajar siswa. Penelitian ini menggunakan metode kuantitatif dengan pendekatan ex-post facto. Subjek pada penelitian ini adalah 136 siswa kelas IV Sekolah Dasar. Instrumen yang digunakan adalah angket. Teknik analisis data menggunakan analisis regresi. Hasil penelitian menunjukkan bahwa peranan dalam keterlibatan orang tua terhadap motivasi siswa mencapi 39,7\%. Dapat disimpulkan bahwa keterlibaatan orang tua memiliki pengaruh positif terhadap motivasi belajar siswa. Penelitian ini menujukkan pentingnya peran orang tua pada motivasi belajar siswa. Hasil penelitian ini diharapkan bisa memberi pemahaman pada pihak sekolah agar mengingatkan para orang tua siswa bahwa dukungan mereka sangat penting dalam proses pembelajaran. Oleh karena itu, semua pihak harus terlibat dalam meningkatkan kualitas pendidikan anak-anak.
\end{abstract}

\section{Keywords: \\ Parental Involvement, Learning Motivation, Learning Facilities}

How to Cite: Alfiansyah, H. R. (2019). The Role of Parental Involvement Towards the Students' Learning Motivation. Lentera Pendidikan : Jurnal Ilmu Tarbiyah dan Keguruan, 22(2), 276-283.

\section{INTRODUCTION}

Basically, education does not only take place within the scope of formal education. Family as informal education also has a role in developing children's education. Schools and families are important factors in education (Spera, Wentzel, \& 
Matto, 2009; Hirsto, 2010). Family involvement can have a positive impact on children's learning at home (Grant \& Ray, 2013; Jeynes, 2014; Robinson \& Harris, 2014). Parents are fully responsible for education within the family. This responsibility can be done when parents engage in students' activities at home. Parental involvement plays a role in building the social, emotional, and academic development of children (Cohen, McCabe, Michelli, \& Pickeral, 2009; Galindo \& Sheldon, 2012; Alamaeda-Lawson \& Lawson, 2016; Berkowitz et al., 2017).

Parental involvement is the consciously active involvement to contribute on a child's education (Avvisati, Besbas, \& Guyon, 2010; Dwiningrum, 2011; Slameto, 2013; Baquedano-Lopez, Alexander, \& Hernandez, 2013; Robinson \& Harris, 2014; Berkowitz et al., 2017). This involvement can be done in the forms of planning, implementation, and evaluation in every home study activity. In line with that opinion, Hornby \& Lafaele (2011) reveal that parents who believe that their children's education not only depends on the scope of the formal school, will be responsible and willing to be actively involved in their children's education. Thus, parental involvement in children's education is needed. Therefore, parents should participate in the educational aspect of their children.

The parental involvement can be measured in many ways, including activities done by parents at both home and school and the parents' positive attitude towards their children's education (D. R. Topor, Keane, Shelton, \& Calkins, 2010; Berkowitz et al., 2017). The kinds of parental involvement may include physical involvement as well as non-physical involvement. Physical involvement is more to the provision of concrete objects in the support of education such as providing the learning facilities and the learning tools at home. The learning facilities play a role in facilitating the process of home-based learning (E. Murray, McFarland-Piazza, \& Harrison, 2015). The forms of the provision of learning facilities can be a decent study room, the provision of learning lights, a desk for study, and various other physical forms. Provision of learning tools at home among of learning support books, stationery, and various other learning tools. Thus, the provision of learning facilities and the provision of appropriate and optimal learning tools aim to make students feel comfortable when learning. Thus, it is expected that the students will be more motivated in the process of learning at home.

The parents' attention given to children is a form of non-physical involvement. Slameto (2013) explains that the parents' attention is a consciously encouragement given by parents to children, and it can be manifested in the form of guidance, thoughts, and feelings. The attention given by parents in the process of children's education is expected to encourage children to be more active learning. The attentions are given in the form of guidance and direction to the child and providing motivation to learn. Communication is needed when parents give their attention to the child. The establishment of smooth communication between parents and children at home can make it easier for parents to create an atmosphere of learning without pressure and fun. 
The strategies by providing a pleasant environment will foster children's learning motivation (Wentzel \& Brophy, 2014). Motivation is the process of energizing, directing, and providing action to achieve a certain goal (Shunk, Pintrich, \& Meece, 2010; Santrock, 2011; Lai, 2011; Tohidi \& Jabbari, 2010; Wentzel \& Brophy, 2014). Motivation will encourage a person to do activities to achieve goals or desires. If it is associated with the learning process, motivation is the driving force that can improve the learning process to achieve the desired goals (Uno, 2010; Winkel, 2012; Sardiman, 2014). Learning motivation can be influenced by several factors. These factors can be divided into two, namely internal factor and external factor. Internal factors are everything that comes from within the person itself, physic and physical maturity, while external factors include everything that comes from outside, such as the form of learning environment.

(Shunk, Pintrich, \& Meece (2010) suggests that motivation can influence the learning process from previously learned skills, strategies, and behaviors. One of the factors that can affect learning motivation is learning facilities (Syah, 2010). Parents who have a conscious motivation for their children's education will certainly give everything for their children's education. This is because the motivation of the parents will also have an impact on the motivation of their children (Santrock, 2011; Avvisati et al., 2010; Jasis \& Ordoñez-Jasis, 2012). Therefore, parents will try to meet the learning needs of children in order to increase the motivation of children in learning.

Based on the theoretical foundation above, the researcher assumes that there is a positive influence of the form of parental involvement given to the child's learning motivation. Not all parents have the same level of giving their form of engagement. This is because the form of parental involvement in teaching and learning activities at home is different in each student. There are several students who get the involvement of parents in the form of adequate learning facilities such as procurement of learning support books, special room learning, and comfortable learning conditions. Yet, there are also some parents who do not give the optimal involvement, both in the physical and non-physical form to their children. This research aims to identify the extent to which the contributions of parents' involvement in children's learning motivation.

\section{METHOD}

This research was conducted using quantitative method. The approach of the research was ex-post facto. The subjects of the research were chosen with random selection. A total number of 136 samples were randomly selected from fourth grade students of elementary school. The instrument used was questionnaire. The techniques of data analysis used were regression analysis and descriptive statistic. The instrument of the research was previously tested towards 30 students in order to gain the validity and reliability of the instrument. Normality and linearity tests were done before the hypothesis test conducted. 


\section{RESEARCH RESULT AND DISCUSSION}

\section{Result of Normality Test}

Normality test was conducted in order to identify whether the data were distributed normally or not. The result of the normality test was presented in table 1.

Table 1. Result of Normality Test

\begin{tabular}{llll}
\hline \multicolumn{1}{c}{ Variable } & Sig. of Count & Std. Sign & Result \\
\hline Parental involvement & 0.547 & 0.05 & Normal \\
Learning motivation & 0.612 & 0.05 & Normal \\
\hline
\end{tabular}

Based on the table above, both variables had normal distribution since the significance value was more than $0.05(>0.05)$. The Kolmogrov Smirnov value for parental involvement variable with significance value 0.547 and the learning motivation variable reached 0.612 .

\section{Result of Linierity Test}

Linierity test was conducted in order to identify whether both variables had linear connection or not. The result of liniarity test was presented in the table 2 .

Table 2. Result of Linierity Test

\begin{tabular}{|c|c|c|c|c|}
\hline Variable & & $\begin{array}{l}\text { Sig. Deviation of } \\
\text { Linierity }\end{array}$ & $\begin{array}{c}\text { Sig. } \\
\text { Linierity }\end{array}$ & Result \\
\hline $\begin{array}{l}\text { Parental involvement } \\
\text { learning motivation }\end{array}$ & towards & 0.895 & 0.000 & Linier \\
\hline
\end{tabular}

In reference to the table above, it could be concluded that the connection between both variables had the Sig. Liniarity under 0.05 and the Sig.Deviation was more than 0.05. Thus, the connection of both variable was linear.

The data were analyzed using Regression analysis. The descriptive analysis could be presented in the table 3 .

Table 3. Descriptive statistic

\begin{tabular}{llllllll}
\hline & N & Mean & Median & Mode & St. Deviation & Minimum & Maximum \\
\hline $\begin{array}{l}\text { Parental } \\
\begin{array}{l}\text { involvement } \\
\text { Learning } \\
\text { motivation }\end{array}\end{array}$ & 136 & 71.46 & 72.00 & 80 & 10.865 & 45 & 94 \\
\hline
\end{tabular}

\section{The Result of Parental Involvement}

The data showed that the mean value reached 71.46 , the median value reached 72 , the mode value reached 80 , the deviation standard reached 10.865 , the minimum score was 45 , and the maximum score was 94 . The result of parental involvement could be presented in the table 4 . 
Table 4. Category of Parental Involvement

\begin{tabular}{lllll}
\hline No & \multicolumn{1}{c}{ Interval } & Frequency & \multicolumn{1}{c}{ Percentage } & Category \\
\hline 1. & $82.315 \leq \mathrm{X}$ & 24 & $17.39 \%$ & High \\
2. & $60.595 \leq \mathrm{X}<82.315$ & 89 & $64.49 \%$ & Medium \\
3. & $\mathrm{X}<60.595$ & 25 & $18.12 \%$ & Low \\
& Total & 136 & $100 \%$ & \\
\hline
\end{tabular}

Based on the table above, the level of fourth the grade students' parental involvement could be categorized in medium category with 89 respondents. The low category reached 25 respondents and the high category reached 24 respondents.

\section{The Result of Learning Motivation}

The data showed that the mean value reached 90.35, the median value reached 91, the mode value reached 87 , the deviation standard reached 13.528, the minimum score was 59 , and the maximum score was 118 . The data could be summarized in the table 5 .

Table 5. Category of Learning Motivation

\begin{tabular}{lllll}
\hline No. & \multicolumn{1}{c}{ Interval } & \multicolumn{1}{c}{ Frequency } & \multicolumn{1}{c}{ Percentage } & Category \\
\hline 1. & $103.878 \leq \mathrm{X}$ & 27 & $19.56 \%$ & High \\
2. & $76.822 \leq \mathrm{X}<103.878$ & 86 & $62.32 \%$ & Medium \\
3. & $\mathrm{X}<76.822$ & 25 & $18.12 \%$ & Low \\
& Total & 136 & $100 \%$ & \\
\hline
\end{tabular}

Based on the table 5, the level of the fourth grade students' learning motivation could be categorized in medium category with 86 respondents. The low category reached 25 respondents and the high category reached 27 respondents.

\section{The Result of Regression Analysis}

Based on the data analysis using SPSS 20, it could be identified that the t-test reached 9.386 and the significance value reached 0.000 . Since the significance value reached 0.000 , it meant that $0.000<0.05$. Thus, the result of the research was accepted. Meanwhile, the contribution of $\mathrm{R}^{2}$ reaches 0.397 (39.7\%). It meant that the parental involvement contributed $39.7 \%$ toward learning motivation. The regression equation was presented below.

$$
Y^{\prime}=36.274+0.761 X
$$

Based on the above equation, the constant value was 36.274. Hence, if the value of parent involvement was 0 then the value of students' learning motivation was 36.274. Regression value of parental involvement was 0.761 which meant in every $1 \%$ increase of parental involvement, the students' learning motivation would increase $0.761 \%$. Thus, it could be concluded that there was a positive influence between the involvement of parents to the learning motivation of the fourth grade students of elementary school. 
The result of the research showed that the parental involvement had positive influences toward the students' learning motivation. The role of parental involvement has contribution to students' learning motivation. Thus, the students who got adequate and optimal support from their parents would have a better learning motivation and vice versa. This result was in line with Räty, Kasanen, \& Laine (2009), they stated that the parental involvement gave a high contribution to the children's education. Educated parents realized that their children's education was important, they would actively engaged their children's education activities such as choosing the right school, providing the learning facilities, and even attending the school committee meeting.

Dwiningrum (2011) explained that parental involvement in education had a positive influence in improving students' learning motivation. Home as a base of education would be achieved by completing the educational facilities (Istadi, 2011). Parents who realized the importance of their children's education, would try to meet all the educational needs of their children. Learning facilities were one form of physical involvement that is given by parents. Amirin (2011) argued that the facility was a means and infrastructure needed in conducting or to expedite an activity. Learning facilities were tools or objects that could support children's learning activities, with learning facilities, children would be more eager to learn, children would be motivated in learning, and the achievement would increase.

Learning facilities contributed the most in the form of involvement provided by parents reached $32.32 \%$ to learning motivation. The fulfillment of learning facilities did not have to spend an expensive cost. Physical involvement could also be the provision of home study aids that in this study contributed $23.77 \%$ to the learning motivation. Learning aids could be in the form of the provision of learning support books, ruler supply, colored pencils, bows, and other tools. Children's learning needed also depend on the role of these aids. The forms of non-physical involvement given by parents to their children in the form of giving guidance and direction to children contributed $18.38 \%$ and the provision of learning motivation contributed $25.53 \%$.

In other researches, the increasing of parental involvement was significantly influence the children's cognitive aspect (Topor, Keane, Shelton, \& Calkin, 2011; Jasis \& Ordoñez-Jasis, 2012; Antoine, 2015; Berkowitz, 2017). In line with this argument, Murray, Mcfarland-piazza, \& Harrison (2015) stated that the parents who were actively engaged in their children activities would have a better communication with their children. Furthermore, it had a positive effect towards the children's education. Based on the research, it could be concluded that the parental involvement has positive influence towards the students' learning motivation. The provision of learning facilities, learning tools, and guidance gives a significant effect towards the students' learning motivation. Thus, it was expected that parents would realize their role is important in the development of their children education. 


\section{CONCLUSION}

Based on the result, the parental involvement had a positive influence on the students' motivation. The biggest contribution of parental involvement was learning facilities included learning support books, proper study rooms, the provision of study lamps, study desks, and various other physical forms. Thus, the students were expected to be more motivated in the learning process at home.

\section{REFERENCES}

Alamaeda-Lawson, T., \& Lawson, M. (2016). Ecologies of Collective Parent Engagement in Urban Education. Urban Education, 1-36. https://doi.org/ $10.1177 / 0042085916636654$

Amirin, T. A. (2011). Manajemen Pendidikan. Yogyakarta: UNY Press.

Avvisati, F., Besbas, B., \& Guyon, N. (2010). Parental Involvement in School: A Literature Review. Revue D'économie Politique, 759-779. https://doi.org/ 10.3917/redp.205.0759

Baquedano-Lopez, P., Alexander, R. A., \& Hernandez, S. J. (2013). Equity Issues in Parentaland Community Involvement in Schools: What Teacher Educators Need to Know. Review of Research in Education, 37, 149-182.

Berkowitz, R., A., A. R., Pineda, D., DePedro, K. T., Weiss, E. L., \& Benbenishty, R. (2017). Parental Involvement and Perceptions of School Climate in California. Urban Education, 1-13.

Cohen, J., McCabe, L., Michelli, N. M., \& Pickeral, T. (2009). School Climate: Research, Policy, Practice, and Teacher Education. Teachers College Record, 180-213.

Dwiningrum, S. I. A. (2011). Desentralisasi dan Keterlibatan Masyarakat dalam Pendidikan. Yogyakarta: Pustaka Pelajar.

Galindo, C., \& Sheldon, S. B. (2012). School and Home Connections and Children's Kindergarten Achievement Gains: The Mediating Role of Family Involvement. Early Childhood Research Quarterly, 27, 90-103.

Grant, K. B., \& Ray, J. A. (2013). Home, School, and Community Collaboration. Los Angeles: Sage Publication, Inc.

Hirsto, L. (2010). Strategies in Home and School Collaboration Among Early Education Teachers. Scandinavian Journal of Education Research, 54(2), 99-108. https://doi.org/10.1080/00313631003637857

Hornby, G., \& Lafaele, R. (2011). Barriers to Parental Involvement in Education: an Explanatory Mode. Educational Review, 63(1), 37-52.

Istadi, I. (2011). Istimewakan Setiap Anak. Bekasi: Pustaka Inti.

Jasis, P. M., \& Ordoñez-Jasis, R. (2012). Latino Parent Involvement. Urban Education, 47(1), 65-89. https:/ / doi.org/10.1177/0042085911416013

Jeynes, W. H. (2014). Parental Involvement That Works ... Because tt's AgeAppropriate. Kappa Delta Pi Record, 50(2), 85-88.

Lai, R. (2011). Motivation: A Literature Review. Boston: Pearson Education, Inc. 
Murray, E., Mcfarland-piazza, L., \& Harrison, L. J. (2015). Changing Patterns of ParentTeacher Communication and Parent Involvement from Preschool to School, 185(7), 1031-1052. https://doi.org/10.1080/03004430.2014.975223

Murray, E., McFarland-Piazza, L., \& Harrison, L. J. (2015). Changing Patterns of ParentTeacher Communication and Parent Involvement from Preschool to School. Early Child Development and Care, 185(7), 1031-1052.

Räty, H., Kasanen, K., \& Laine, N. (2009). Parents' Participation in Their Child's Schooling. Scandinavian Journal of Educational Research, 53(3), 277-293. https://doi.org/10.1080/00313830902917352

Robinson, K., \& Harris, A. L. (2014). The Broken Compass: Parental Involvement with Children's Education. Cambridge, MA: Harvard University Press.

Santrock, J. W. (2011). Educational Psychology (5th Edition). New York: The McGraw-Hill Companies, Inc.

Sardiman. (2014). Interaksi \& Motivasi Belajar Mengajar. Jakarta: Rajawali Pers.

Shunk, D. H., Pintrich, P. R., \& Meece, J. L. (2010). Motivation in Education. Boston: Pearson Education, Inc.

Slameto. (2013). Belajar dan Faktor-faktor yang Mempengaruhi. Jakarta: Rineka Cipta.

Spera, C., Wentzel, K. R., \& Matto, H. C. (2009). Parental Aspirations for Their Children's Educational Attainment: Relations to Ethnicity, Parental Education, Children's Academic Performance, and Parental Perceptions of School Climate. Journal of Youth and Adolescence, 38.

Syah, M. (2010). Psikologi Pendidikan dengan Pendekatan Baru. Bandung: PT Remaja Rosdakarta.

Tohidi, H., \& Jabbari, M. M. (2010). The Effects of Motivation in Education. Social and Behaviora Sciences, 31, 820-824.

Topor, D. A., Keane, S. B., Shelton, T. L., \& Calkins, S. D. (2011). Parent Involvement and Student Academic Performance: A Multiple Mediational Analysis. J Prev Interv Community, 38(3), 183-197. https://doi.org/10.1080/10852352.2010. 486297.Parent

Topor, D. R., Keane, S. P., Shelton, T. L., \& Calkins, S. D. (2010). Parent Involvement and Student Academic Performance: A Multiple Mediational Analysis. Journal of Prevention E Intervention in the Community, 38(3), 183-197.

Uno, H. (2010). Teori Motivasi dan Pengukurannya. Jakarta: PT Bumi Aksara.

Wentzel, K. R., \& Brophy, J. E. (2014). Motivation Student to Learn (4th Edition). New York: Routledge.

Winkel, W. (2012). Psikologi Pengajaran. Yogyakarta: Media Abadi. 